Louisiana State University

LSU Digital Commons

$9-2020$

The pull-to-stay effect: influence of sales managers' leadership worthiness on salesperson turnover intentions

Vishag Badrinarayanan

Aditya Gupta

Nawar N. Chaker

Follow this and additional works at: https://digitalcommons.Isu.edu/marketing_pubs

Part of the Business Commons 


\section{Journal of Personal Selling \& Sales Management}

\section{The pull-to-stay effect: influence of sales managers' leadership worthiness on salesperson turnover intentions}

\section{Vishag Badrinarayanan , Aditya Gupta \& Nawar N. Chaker}

To cite this article: Vishag Badrinarayanan , Aditya Gupta \& Nawar N. Chaker (2020): The pull-tostay effect: influence of sales managers' leadership worthiness on salesperson turnover intentions, Journal of Personal Selling \& Sales Management, DOI: 10.1080/08853134.2020.1820347

To link to this article: https://doi.org/10.1080/08853134.2020.1820347

冓 Published online: 18 Sep 2020.

Submit your article to this journal

Lll Article views: 298

Q View related articles

View Crossmark data 


\title{
The pull-to-stay effect: influence of sales managers' leadership worthiness on salesperson turnover intentions
}

\author{
Vishag Badrinarayanan ${ }^{a}$, Aditya Gupta ${ }^{a}$, and Nawar N. Chaker ${ }^{b}$ \\ ${ }^{a}$ McCoy College of Business Administration, Texas State University, San Marcos, 78666 Texas, USA; ${ }^{b}$ E.J. Ourso College of Business, Louisiana \\ State University, Baton Rouge, 70803 Louisiana, USA
}

\begin{abstract}
Given that salesperson turnover is a significant problem for sales organizations, sales researchers have devoted a lot of attention toward explicating various drivers and mitigators of salesperson turnover intentions. Within this domain, consistent with the popular sentiment "employees don't quit their jobs, they quit their bosses," scholars have explored sales manager-related triggers such as leadership style, salesperson - sales manager relational exchange, and several managerial characteristics. We extend this stream of research by developing and testing a framework of salespersons' perceptions of their manager's leadership worthiness - a higher-order construct comprising of competence, charisma, and behavioral integrity - and its subsequent impact on salesperson turnover intentions. Our framework illustrates that salespersons' inferences, judgments, and attributions regarding their manager exert a pull-to-stay effect by lowering turnover intentions. Specifically, we find that leadership worthiness mitigates turnover intentions directly and indirectly via personal identification with and trust in the manager. We also find support for the moderating effects of salesperson gratitude on the relationships between leadership worthiness and both salesperson turnover intentions as well as identification with the manager. We conclude by discussing theoretical and practical implications of our findings as well as directions for future research.
\end{abstract}

\section{ARTICLE HISTORY}

Received 13 April 2020

Accepted 2 September 2020

\section{KEYWORDS}

Sales leadership; leadership worthiness; turnover intentions; identification with manager; trust in manager; gratitude
Although sales organizations devote a large amount of resources toward identifying, acquiring, and retaining sales talent, sales force turnover continues to be a significant problem (e.g., Boles et al. 2012; Sunder et al. 2017). According to industry estimates, turnover rates among salespeople hover between $20 \%$ to $34 \%$ if both voluntary and involuntary turnover are considered (Comaford 2016). Such high turnover rates not only impose severe financial, operational, relational, and reputational costs on organizations, but also erode revenue, profitability, and competitive advantage (Boles et al. 2012; Darmon 2008; Jaramillo et al. 2009). Thus, stemming salesperson turnover remains an important goal for organizations and a critical area for sales research (Boles et al. 2012; Jones et al. 2007).

While extant research has examined various salespersonrelated, work-related, peer-related, and environment-related antecedents of salesperson turnover (e.g., Boles et al. 2012; Brashear et al. 2003; Sunder et al. 2017), studies have also investigated sales manager-related antecedents such as leadership styles (e.g., Jaramillo et al. 2009), salesperson - sales manager relational exchange (Darrat, Atinc, and Babin, Griffin, and Hair 2016), and specific managerial characteristics and behaviors (e.g., Brashear et al. 2003; Jones et al. 1996). The role of sales managers in influencing turnover intentions is also echoed in the popular press through phrases such as "employees don't quit their jobs, they quit their bosses" and reports that exiting employees would have stayed had their manager done something to prevent them from quitting their job (Gallup 2019). This emphasis on sales managers in mitigating turnover intentions is not surprising given that they are essential links between the sales force and the organization and, often, serve as proximal influencers of a variety of job-related outcomes among salespeople (Badrinarayanan, Ramachandran, and Madhavaram 2019a; Guenzi et al. 2019; Plank et al. 2018; Skiba, Saini, and Friend 2019). As sales organizations become flatter and sales managers acquire larger spans of control (Ingram et al. 2005), the linkage between effective sales leadership and turnover intention will only become more critical.

This study extends the literature on sales leadership and turnover intentions by focusing on the construct of leadership worthiness and demonstrating that sales managers' leadership worthiness can exert a "pull-to-stay" effect on salespeople (Waldman, Carter, and Hom 2015). Broadly stated, leadership refers to the execution of a set of activities for guiding, directing, or influencing individuals to achieve goals that benefit the organization (Ingram et al. 2005). Yet, as leadership theorists posit, effective leadership is contingent upon not only the enactment of prescribed activities, but also the perception among subordinates that a leader is a "worthy" target to be followed (Liborius 2014; Thompson et al. 2008). Indeed, studies have demonstrated that 


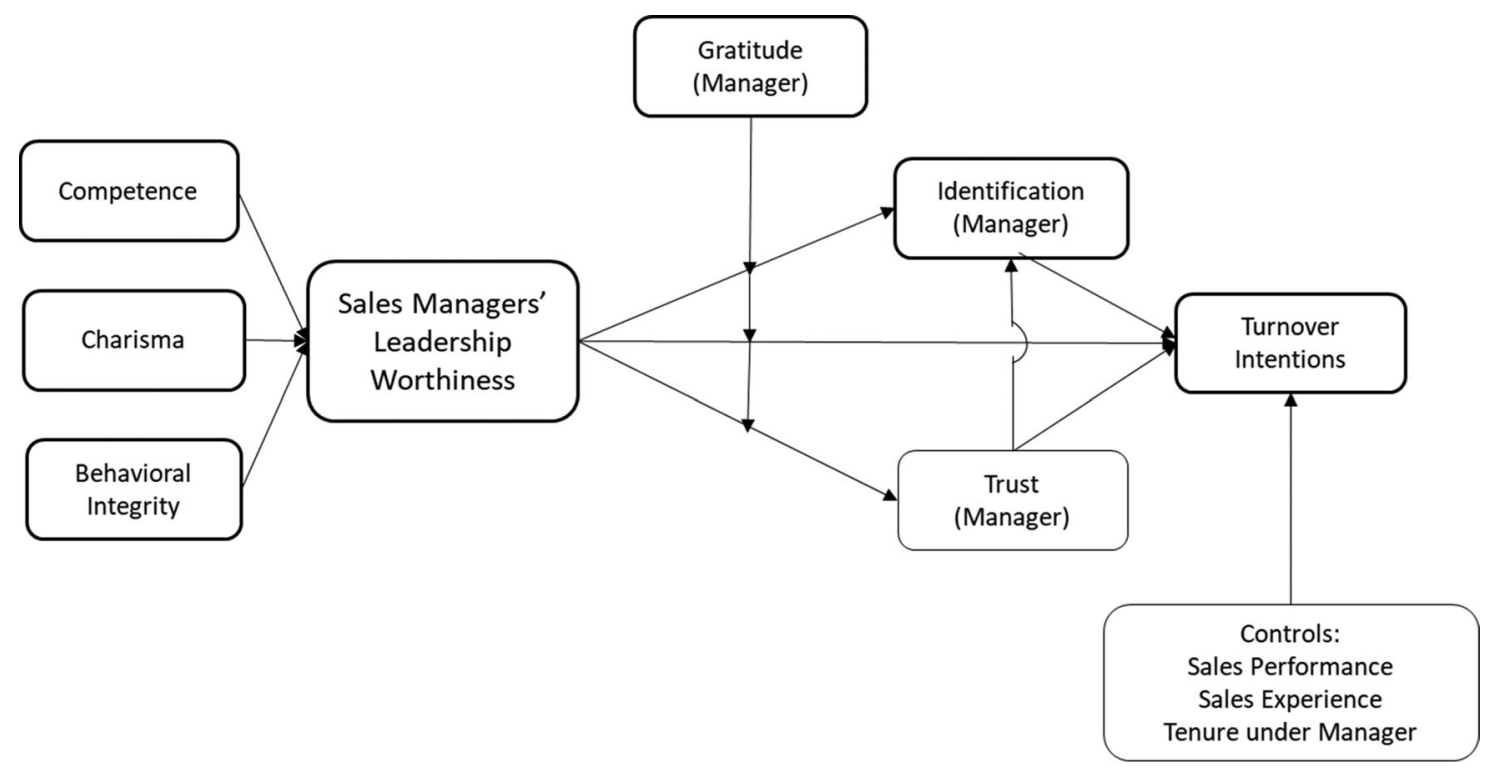

Figure 1. Conceptual and theoretical framework.

managers who are perceived to demonstrate leadership worthiness are more likely to gain follower acceptance and be deemed as attractive targets for being followed (Liborius 2014; Thompson et al. 2008). Extending leadership research that posits that perceptions of worthy leadership are composed of evaluations of abilities, influence, and character (Thompson et al. 2008), we define sales managers' leadership worthiness as the extent to which sales managers are perceived as (1) possessing appropriate knowledge, skills, and abilities (i.e., competence), (2) exerting influence by articulating goals and motivating followers through confident and inspirational leadership (i.e., charisma), and (3) enacting espoused values such that there is consistency between their words and deeds (i.e., behavioral integrity). Correspondingly, drawing from prior research in the sales and leadership literature, we develop and test a theoretical framework that illustrates the direct as well as indirect influence of sales managers' leadership worthiness on salespersons' turnover intentions (See Figure 1).

Our conceptualization of leadership worthiness and the proposed framework address several important gaps germane to the sales management literature. First, although prior research has examined leadership styles and characteristics as antecedents of turnover intentions (e.g., Jaramillo et al. 2009), theoretical frameworks on managerial influence have been criticized as being too restrictive or skewed toward constructs akin to capabilities and calls have been raised for the development of leadership constructs that encapsulate a broader cluster of relevant attributes (Peesker et al. 2019; Thompson et al. 2008). Accordingly, we draw on the notion of worthy leadership (Thompson et al. 2008) and address this limitation by conceptualizing sales managers' leadership worthiness as a higher-order formative construct consisting of three first-order reflective dimensions (i.e., competence, charisma, and behavioral integrity). Second, although researchers have explicated the critical role of manager-salesperson relationships (e.g., Darrat, Atinc, and Babin 2016), it has been pointed out that such relationships alone do not necessarily translate into reduced attrition as salespersons may follow their managers when managers themselves exit the organization (Harris, Kacmar, and Witt 2005). Thus, from the perspective of curbing turnover intentions, there is a need to transcend relational exchanges and explore additional leadership characteristics that solder salespersons to organizations. Correspondingly, we examine the effect of sales managers' leadership worthiness on turnover intentions, in conjunction with relational variables such as salespersons' identification with the manager and trust in the manager. Third, leadership research posits that leaders are more endearing and effective "if they act leaderlike and obtain good performance" (Jacquart and Antonakis 2015, 1052). That is, inferences about the leader that provide indications of future effectiveness and attributions of performance that provide indications of past effectiveness are both critical in evaluations of leaders and subsequent follower outcomes (Jacquart and Antonakis 2015).

Therefore, we investigate how salespersons' gratitude toward the sales manager, the positive emotional response to past managerial support that triggers a desire to reciprocate (Palmatier et al. 2009), moderates the effect of sales managers' leadership worthiness on salespersons' identification with the manager, trust in the manager, and turnover intentions. In the following sections, we review relevant background literature, describe leadership worthiness and its constituent dimensions, introduce our framework and hypothesized relationships, present analytical procedures, and conclude with a discussion of our results for theory and practice.

\section{Background}

As salespeople operate as boundary spanners in extensive ecosystems, with responsibilities for developing and managing both internal and external relationships, they are pivotal to organizational success (Hartmann, Wieland, and Vargo 2018). Therefore, in addition to other key job-related metrics (e.g., salesperson performance, job satisfaction), 
salesperson turnover, or the incidence of salespersons exiting an organization (Jaramillo, Mulki, and Boles 2013), is of critical importance. High salesperson turnover can result in several direct and indirect costs to an organization such as losses in revenue, investments in salesperson development and incentivization, tacit knowledge, customer opportunities, salesperson-owned customer relationships, and vital links in intra- and inter-organizational networks (Gupta et al. 2019; Sunder et al. 2017). Organizations will also need to invest extensive resources toward recruiting, training, and onboarding replacement salespeople and such investments typically consume valuable time before they result in any positive returns for the organization (Shi et al. 2017). Given that salesperson turnover poses entropic challenges and threats to the sales ecosystem, sales researchers have employed various theoretical bases to examine distinct antecedents of salesperson turnover across B2B (e.g., Jones et al. 1996), B2C (e.g., Flaherty and Pappas 2002) and direct selling (e.g., Jaramillo, Mulki, and Boles 2013) contexts.

Within this domain, extending the perspective that leadership variables must be explicitly included in frameworks of turnover theory in sales settings (Jones et al. 1996), prior research has focused attention on the role of sales managers in influencing turnover intentions. Indeed, through their actions, interactions, and leadership styles, managers play a crucial role in influencing and shaping salesperson jobrelated attitudes and behaviors (e.g., DeConinck 2011), sales success or failures (Ingram et al. 2005; Lewin and Sager 2010), and, importantly, salesperson turnover intentions and turnover rates (Shanahan and Hopkins 2019). Specifically, as illustrated in Table 1, prior research has identified various sales manager-related antecedents of salesperson turnover intentions such as leadership style, supervision and support, policies and controls, and financial allocations, among others (See Table 1 for a review).

Although extant research has provided meaningful insights on the relationship between managerial factors and turnover intentions, there is a need for further investigation of sales leadership at the middle management level (Ingram et al. 2005) and better delineation of salespersons' perceptions of sales managers' leadership characteristics (Guenzi et al. 2019; Plank et al. 2018). Toward this end, we draw from the leadership literature to explicate how sales managers' leadership worthiness influences salespersons' propensity to leave an organization. Research on implicit leadership theories (ILT) suggests that followers' perceptions and evaluations are important in their recognition of someone as a leader, which then evokes favorable follower responses (Chaker et al. 2019; Lord and Alliger 1985). That is, followers are thought to possess cognitive schemas of what traits and behaviors leaders ought to exhibit and, consequently, engage in an implicit and automatic process of leadership categorization to determine whether someone is a leader (Lord and Alliger 1985). In this regard, studies in the leadership literature have proposed that managers who are perceived to demonstrate "worthy" leadership are more likely to be deemed as attractive targets for being followed and evoke appropriate followership outcomes (Liborius 2014; Thompson et al. 2008).

Specifically, defining worthy leadership as "the ability to guide, direct, or influence people in a way that has great merit, character, and value," Thompson et al. $(2008,366)$ theorize that worthy leaders stand out from others by excelling across three major categories: the capacity to lead, the commitment to lead, and the character to lead. The capacity category captures what managers can do in their leadership roles and refers to the possession of knowledge, skills, and abilities required for effective leadership (Thompson et al. 2008). The commitment category focuses on what managers want to do as well as how they go about doing it and refers to not only how managers define success, but also their passion for results and influencing talent (Thompson et al. 2008). Finally, the character category focuses on what managers will do in different contexts and refers to behavioral aspects such as personal integrity, openness, and humility (Thompson et al. 2008).

Extending the framework outlined by Thompson et al. (2008) to the sales domain, this study's conceptualization of sales managers' leadership worthiness incorporates three sub-dimensions that are idiosyncratic to the sales context, in general, and sales manager leadership, in particular: competence, charisma, and behavioral integrity. Competence refers to a salesperson's perceptions regarding their sales manager's ability, which subsumes skills and characteristics that enable the manager to exert influence and function effectively (Mayer and Davis 1999). Managers who possess requisite qualifications, demonstrate adequate knowledge, and contribute effectively to the fulfillment of organizational objectives are likely to be perceived as more competent than others (Schetzsle and Delpechitre 2013). Competent sales managers are valuable resources to salespersons and engender positive evaluations, cooperation, trust, and commitment to the manager (Schetzsle and Delpechitre 2013). Therefore, competence aligns with the capacity to lead dimension proposed by Thompson et al. (2008).

Charisma draws attention to subordinates' perceptions regarding how managers demonstrate commitment to organizational goals and vision, articulate messages, and inspire behaviors (Hwang, Khatri, and Srinivas 2005). According to Wieseke et al. $(2009,126)$, "charismatic leaders are those who possess high sensitivity to the environment and followers' needs, articulate an attractive vision for the organization, and inspire subordinates to follow their attitudes and behaviors." Charismatic leaders transform followers' perceptions about work and inspire them to transcend personal goals in order to achieve idealized goals (Shamir, House, and Arthur 1993). Charisma may also be thought of as a source of referent and expert power (Halpert 1990), which have each been shown to lead to both supervisor and organization-related outcomes (Kudisch et al. 1995). Prior research has illustrated that managers' charisma influences followers' attitudes, behavior, motivation, trust in the leader, role conflict, role ambiguity, personal identification with the leader, organizational identification, and job performance (Conger, Kanungo, and Menon 2000; Shamir, 
Table 1. Summary of illustrative research on managerial factors related to salesperson turnover.

\begin{tabular}{|c|c|c|c|c|c|}
\hline Authors & Context & Theoretical Approach & IVs & Mediators & $\begin{array}{l}\text { Key Findings Related to } \\
\text { Salesperson Turnover }\end{array}$ \\
\hline Johnston et al. (1990) & $\begin{array}{l}\text { B2B, Consumer } \\
\text { goods company }\end{array}$ & $\begin{array}{l}\text { Organizational } \\
\text { commitment } \\
\text { framework (MPS) }\end{array}$ & $\begin{array}{l}\text { Leadership behaviors, } \\
\text { role conflict, } \\
\text { role ambiguity }\end{array}$ & $\begin{array}{l}\text { Job satisfaction, } \\
\text { organizational } \\
\text { commitment, } \\
\text { propensity to leave }\end{array}$ & $\begin{array}{l}\text { Leadership behavior indirectly } \\
\text { impacts turnover intentions } \\
\text { though job stress, job } \\
\text { satisfaction, and } \\
\text { organizational commitment. }\end{array}$ \\
\hline Jones et al. (1996) & $\begin{array}{l}\text { B2B, Consumer goods } \\
\text { manufacturer }\end{array}$ & $\begin{array}{l}\text { Models of } \\
\text { employee turnover }\end{array}$ & $\begin{array}{l}\text { Leadership behaviors, } \\
\text { role conflict, } \\
\text { ambiguity }\end{array}$ & $\begin{array}{l}\text { Job anxiety, job } \\
\text { satisfaction, } \\
\text { propensity to leave }\end{array}$ & $\begin{array}{l}\text { Sales manager leadership } \\
\text { behaviors directly and } \\
\text { indirectly impact job } \\
\text { satisfaction, which } \\
\text { influences salesperson } \\
\text { propensity to leave and } \\
\text { actual turnover. }\end{array}$ \\
\hline Brashear et al. (2003) & B2B, Multiple industries & Trust-building processes & $\begin{array}{l}\text { Managerial } \\
\text { opportunism, } \\
\text { managerial respect, } \\
\text { shared values }\end{array}$ & $\begin{array}{l}\text { Salesperson trust, job } \\
\text { satisfaction, } \\
\text { relationalism, } \\
\text { organizational } \\
\text { commitment }\end{array}$ & $\begin{array}{l}\text { Salesperson trust in the } \\
\text { manager indirectly impacts } \\
\text { organizational commitment } \\
\text { and turnover intentions. }\end{array}$ \\
\hline $\begin{array}{l}\text { Brashear, Manolis, and } \\
\text { Brooks (2005) }\end{array}$ & B2B, Multiple industries & $\begin{array}{l}\text { Organizational } \\
\text { justice theory }\end{array}$ & $\begin{array}{l}\text { Process control, } \\
\text { decision control }\end{array}$ & $\begin{array}{l}\text { Trust, procedural justice, } \\
\text { distributive justice }\end{array}$ & $\begin{array}{l}\text { Managers who give } \\
\text { salespeople control into } \\
\text { decisions and process } \\
\text { garner more trust, which } \\
\text { leads to increased } \\
\text { perceptions of distributive } \\
\text { and procedural justice, and } \\
\text { lower turnover intentions. }\end{array}$ \\
\hline Jaramillo et al. (2009) & Multiple industries & $\begin{array}{l}\text { Servant } \\
\quad \text { leadership theory }\end{array}$ & Servant leadership & $\begin{array}{l}\text { Ethical level, person- } \\
\text { organization fit, } \\
\text { organizational } \\
\text { commitment }\end{array}$ & $\begin{array}{l}\text { Servant leadership affects } \\
\text { turnover intentions via a } \\
\text { complex moderated and } \\
\text { mediated chain-of-effects } \\
\text { that includes ethical level, } \\
\text { person-organization fit, and } \\
\text { organization commitment. }\end{array}$ \\
\hline DeConinck (2011) & Multiple industries & $\begin{array}{l}\text { Social exchange theory, } \\
\text { LMX theory }\end{array}$ & $\begin{array}{l}\text { Leader-member } \\
\text { exchange, } \\
\text { organizational } \\
\text { identification }\end{array}$ & $\begin{array}{l}\text { Performance, } \\
\text { organizational } \\
\text { commitment, } \\
\text { turnover intentions }\end{array}$ & $\begin{array}{l}\text { Organizational commitment } \\
\text { mediates the relationships } \\
\text { between leader-member } \\
\text { exchange, organizational } \\
\text { identification, performance } \\
\text { and turnover intention. }\end{array}$ \\
\hline $\begin{array}{l}\text { Mulki, Caemmerer, and } \\
\text { Heggde (2015) }\end{array}$ & $\begin{array}{l}\text { B2C, Software, } \\
\text { insurance, and } \\
\text { banking (in India) }\end{array}$ & $\begin{array}{l}\text { Leadership styles } \\
\text { research, role theory }\end{array}$ & $\begin{array}{l}\text { Participative leadership, } \\
\text { instrumental } \\
\text { leadership }\end{array}$ & $\begin{array}{l}\text { Satisfaction with } \\
\text { supervisor, work } \\
\text { effort, job } \\
\text { performance }\end{array}$ & $\begin{array}{l}\text { There is a negative } \\
\text { relationship between } \\
\text { satisfaction with the } \\
\text { supervisor and turnover } \\
\text { intentions. Power distance } \\
\text { moderates this relationship. }\end{array}$ \\
\hline $\begin{array}{l}\text { Skiba, Saini, and } \\
\text { Friend (2019) }\end{array}$ & B2B, Multiple industries & $\begin{array}{l}\text { Job demands- } \\
\text { resources theory }\end{array}$ & Cost prioritization & $\mathrm{N} / \mathrm{A}$ & $\begin{array}{l}\text { Management's cost } \\
\text { prioritization has } \\
\text { unintended negative } \\
\text { consequences on } \\
\text { salesperson turnover. } \\
\text { Output control and } \\
\text { micromanagement } \\
\text { negatively moderate } \\
\text { this linkage. }\end{array}$ \\
\hline $\begin{array}{l}\text { Shanahan and } \\
\text { Hopkins (2019) }\end{array}$ & B2B, National firm & Virtue ethics research & $\begin{array}{l}\text { Level of agreement } \\
\text { between a } \\
\text { salesperson and } \\
\text { sales manager }\end{array}$ & $\begin{array}{l}\text { Satisfaction with sales } \\
\text { managers, } \\
\text { organizational } \\
\text { commitment }\end{array}$ & $\begin{array}{l}\text { Level of agreement between } \\
\text { sales managers and } \\
\text { salespeople impacts } \\
\text { organizational commitment } \\
\text { and satisfaction with the } \\
\text { sales manager, which } \\
\text { influences salesperson } \\
\text { turnover intentions. }\end{array}$ \\
\hline
\end{tabular}

House, and Arthur 1993; Wieseke et al. 2009). Given that charisma subsumes a manager's commitment to goals, vision, and followers, it aligns with the commitment to lead dimension proposed by Thompson et al. (2008).

Behavioral integrity, a quality that followers highly desire in their managers, refers to "the perceived pattern of alignment between an actor's words and deeds" Simons (2002, 19). Assessments of integrity stem from evaluations of past behavior and includes not only the perceived match between espoused and enacted values, but also the extent to which promises are kept (Simons et al. 2007). While assessment of observable leaderlike characteristics such as competence and charisma may be related to perceptions of leader power and effectiveness (Raven 2008), perceived behavioral integrity exemplifies the expectation that there will be consistency between a manager's values and behaviors. When managers 
consistently demonstrate an alignment between what they say and what they do, it reduces uncertainty about their character and enhances their credibility and effectiveness. Prior research has demonstrated that managers' behavioral integrity is critical for important outcomes such as trust in managers, organizational commitment, and firm profitability (Simons et al. 2007). Given that behavioral integrity addresses how managers will behave across a variety of contexts, it aligns with the character to lead dimension proposed by Thompson et al. (2008).

This study's focus on leadership worthiness, in addition to being a new contribution to the sales leadership literature, builds on prior research on multi-attribute assessments of leadership developed in recent years. For instance, in a study on effective leadership and follower outcomes, Liborius (2014) postulates that perceptions regarding a leader's competence and role-modeling as well as loyalty toward the leader influence the extent to which subordinates deem the leader as worthy of being followed. Similarly, in a recent study in the sales literature, Peesker et al. (2019) propose that effective leadership behaviors - pertaining to coaching, collaborating, championing, and customer engaging - influence salesperson performance. Through this study, we advance extant knowledge by responding to calls for empirical validation of the dimensions of leadership worthiness (Thompson et al. 2008), offering a novel configuration of leadership characteristics (Liborius 2014), and, specifically, investigating characteristics of effective sales leadership and their influence on salesperson outcomes (Peesker et al. 2019). Next, leveraging prior work in the sales and leadership literature, we elaborate on the interrelationships among the focal constructs proposed in our theoretical framework.

\section{Hypotheses}

\section{Leadership worthiness and salesperson turnover intentions}

Sales managers play an important role in salespersons' job evaluations and levels of intrinsic motivation. As Costigan et al. $(2011,77)$ note, "The immediate boss affects the employee's daily work life by making operational decisions and providing socio-emotional support that directly impact that employee's job-related well-being." Perceptions of sales managers' leadership worthiness, therefore, becomes critical for mitigating salespersons' turnover intentions. As noted earlier, when sales managers are perceived to be worthy leaders, they demonstrate competence in sales-related knowledge and skills, charismatic influence in articulating and motivating achievement of goals and values, and behavioral integrity by being fair, truthful, and keeping promises. Taken together, these characteristics enhance salesperson perceptions that their manager is a capable, approachable and conscientious problem-solver. Thus, when their manager is perceived as competent, salespersons are less likely to let problems fester and look up to managers for guidance and support (Rich 1997). The accessibility to guidance and support from competent managers can contribute to reduced job stress, greater levels of confidence, and the mindset to approach work challenges from a problemfocused coping approach (Lewin and Sager 2010), which, in turn, help in reducing turnover intentions.

Additionally, salespersons are more likely to act on guidance and suggestions provided by sales managers who are charismatic, as such managers are effective in transforming the needs and aspirations of followers from self-interests to collective interests (Shamir, House, and Arthur 1993; van Knippenberg and Sitkin 2013). Charismatic leaders not only project a sense of mission/vision and set performance expectations that engage followers, but also make personal examples and sacrifices toward achievement of stated collective goals (van Knippenberg and Sitkin 2013). Thus, manager charisma helps in accomplishing stated goals, creating value congruence between salesperson and the manager, and promoting person-job fit (Waldman, Carter, and Hom 2015), which in turn, cultivate stronger relational ties with both the firm and the leader (Sluss and Ashforth 2008).

Further, when managers consistently demonstrate behavioral integrity through alignment between their espoused and enacted values, they positively influence their subordinates' work attitudes and behavior (Simons 2002; Simons et al. 2007). As Davis and Rothstein (2006) note, when managers demonstrate behavioral integrity, it enhances followers' job satisfaction, satisfaction with the manager, and organizational commitment. Similarly, Grisaffe and Jaramillo (2007) suggest that integrity of sales managers helps in promoting positive work attitudes and a sense of achievement among salespeople. Taken together, sales managers' leadership worthiness, which comprises of perceptions regarding a manager's competence, charisma, and behavioral integrity is hypothesized to reduce salesperson turnover intentions. When sales managers are not perceived as worthy leaders, salespeople are less likely to approach them for guidance, buy into organizational goals and objectives, and develop willingness to adhere to stipulated instructions. In turn, such salespeople are likely to experience greater levels of frustration and emotional exhaustion in the workplace (Matthews et al. 2018), which are likely to engender higher turnover intentions. Therefore:

$\mathbf{H}_{\mathbf{1}}$ : Sales managers' leadership worthiness negatively influences salesperson turnover intentions.

\section{Leadership worthiness and identification with sales managers}

According to Ashforth, Schinoff, and Rogers (2016, 28), personal identification refers to the "perceived oneness with another individual, where one defines oneself in terms of the other." In contrast to organizational identification or relational identification, where the target of identification is a work collective or a role-based relationship, respectively, the target for personal identification is a specific individual within the organization. Specifically, with personal identification, an individual identifies with a target individual due to the target's idiosyncratic attributes that define the target and distinguish them from others (Ashforth, Schinoff, and Rogers 2016). Such attributes may include knowledge, skills, 
abilities, values, goals, beliefs, behavior, character, personality and physical appearance among others, although identification may develop based on only those attributes that are perceived to be central, distinct, and enduring to the target (Ashforth, Schinoff, and Rogers 2016). Essentially, when personal identification occurs, an individual's beliefs about a target's attributes become internalized and self-definitional, which in turn, make the individual engage in behaviors to preserve the expanded self, cooperate better with the target, and become more receptive to the target's influence. Employees' personal identification with managers can thus be a "prolific device" for organizations to enable pro-organizational behavior (Fuchs 2011, 562). In particular, when employees develop personal identification with their managers, it evokes a sense of pride in being associated with the manager, respect for the manager, and a desire to emulate the manager's behaviors and characteristics and, consequently, serves as the conduit through which leadership characteristics influence follower outcomes, such as job satisfaction, helping behavior, and performance (Chun et al. 2009).

In a sales context, research on salespersons' identification with managers (Ahearne et al. 2013; Nowlin, Walker, and Anaza 2019) is gaining momentum. While Nowlin, Walker, and Anaza (2019) report a positive link between salespersons' identification with the manager and salesperson performance, Ahearne et al. (2013, 643) demonstrate that interpersonal identification between salespersons and sales managers have "significant incremental effects on important marketing outcomes over and above the influence of their level of organizational identification." Along these lines, we surmise that when sales managers are perceived as worthy leaders, they become attractive targets for personal identification. Through the dimensions of competence, charisma, and behavioral integrity, sales managers can provide guidance, effective coaching, reliable communication, role clarity, and a supportive work environment, while also mitigating workplace anxiety, ambiguity, and stress. In turn, salespersons are likely to gravitate toward such sales managers to fulfill their needs for uncertainty reduction and selfenhancement, which are important pathways to personal identification (Ashforth, Schinoff, and Rogers 2016).

Competent managers consistently demonstrate their knowledge, skills, and abilities to achieve organizational objectives, equip subordinates with requisite capabilities, empower them with skills to combat challenges, facilitate meaningful exchanges, and present the work environment as an opportunity to grow and enhance their own performance. Consequently, through interactions with a competent manager, subordinates are likely to develop favorable evaluations of the manager, sense opportunities to enhance themselves through working and cooperating with the manager, and internalize some of the manager's desirable attributes for self-referential or self-definitional purposes (Ashforth, Schinoff, and Rogers 2016; Schetzsle and Delpechitre 2013). Charismatic leaders tend to act as strong role models, exhibiting behaviors desired by followers and inducing confidence among followers that stated vision/goals can be attained through adoption of specific values and behaviors (Fuchs 2011). The role-modeling of exemplary behaviors evokes pride, respect, and a desire for emulation among followers (Shamir, House, and Arthur 1993). As a result, charismatic leaders can transform followers' self-concept and motivate followers to satisfy their need for a positive self-concept by forging an overlap between their identities and the leader's identity (Shamir, House, and Arthur 1993). As Fanelli and Misangyi (2006) indicate, leader charisma can inspire a sense of confidence and self-efficacy among followers, which lead to admiration for and identification with the leader.

Integrity is suggestive of leaders' ethicality and, as such, subordinates look for behavioral integrity in their leaders and often count on the match between the leader's words and actions for satisfying their own needs while fulfilling workplace responsibilities (Simons 2002). When leaders demonstrate a consistent pattern of transparent and ethical behavior, it sends a strong message to subordinates regarding their beliefs, values, and expectations (Avolio, Walumbwa, and Weber 2009). Consequently, behavioral integrity could satisfy subordinates' self-definitional needs by triggering the desire to change their self-concept to be more in alignment with the leader identity (Pratt 1998). Leaders' behavioral integrity also plays an important role in fostering and maintaining a climate of psychological safety, i.e., the presence of policies and procedures that promote fair, open, and inclusive interactions in the workplace, which can serve as a basis for identity security, or a source of self-affirmation (Baer and Frese 2003). On the basis of these arguments, it is expected that a sales manager's leadership worthiness increases salespersons' identification with the manager. Therefore, we posit:

\section{$\mathbf{H}_{2}$ : Sales managers' leadership worthiness positively influences} salespersons' identification with sales managers.

Through personal identification with managers, individuals not only derive self-enhancement through internalization of desired attributes, but also adjust better to the workplace due to the perceived complementarity in values (Ashforth, Schinoff, and Rogers 2016). As a result, such individuals become more receptive to the manager's influence (Gardner and Avolio 1998), care more about the manager's well-being (Ashforth, Schinoff, and Rogers 2016), cooperate better with the manager's change initiatives (Fuchs 2011), exhibit higher job involvement and job satisfaction (Chun et al. 2009), develop positive organizational attitudes (Ashforth, Schinoff, and Rogers 2016), and perform better (Ahearne et al. 2013). In addition to these outcomes, prior research has empirically demonstrated a link between personal identification with managers and reduced turnover intentions among subordinates (e.g., Miao, Newman, and Lamb 2012). Correspondingly, given that sales managers are the most proximal organizational representatives for salespersons, personal identification with sales managers can enhance evaluations of the workplace and, subsequently, lower turnover intentions. Hence, we propose:

$\mathbf{H}_{3}$ : Salespersons' identification with sales managers negatively influences salespersons' turnover intentions. 


\section{Leadership worthiness and trust in sales managers}

Trust is a vital ingredient and a binding factor in successful relationships (Morgan and Hunt 1994). Formally, trust is defined as "the willingness of a party to be vulnerable to the actions of another party based on the expectation that the other will perform a particular action important to the trustor, irrespective of the ability to monitor or control that other party" (Mayer, Davis, and Schoorman 1995, 712). In organizational settings, where individuals work together in an interdependent manner to achieve professional and personal goals, interpersonal interactions are fraught with risk and uncertainty. In such contexts, the belief that another party's actions will be beneficial, and not detrimental, to one's interests becomes an important guiding force for future expectations and exchanges. Although employees develop interpersonal trust in various organizational referents (e.g., Dirks and Ferrin 2002; Fang et al. 2008), trust in immediate managers is a critical factor for engendering managerial effectiveness. Given that immediate managers influence their subordinates' day-to-day functioning through various monitoring, coaching, support, supervision, and evaluation activities, confidence in the manager's motives and intentions reduces risk and facilitates appropriate relational exchanges as well as reciprocal behaviors. Indeed, systematic research on subordinates' trust in managers has revealed that trust increases positive outcomes such as job satisfaction, performance, and organizational citizenship behaviors and reduces negative outcomes such as intentions to quit (Colquitt, Scott, and LePine 2007; Dirks and Ferrin 2002).

Given the importance of subordinates' trust in managers in engendering favorable work outcomes, studies in the leadership literature as well as the sales literature have investigated various leader-related characteristics as antecedents. This body of work subscribes to the notion that "managers' actions and behaviors provide the foundation for trust and that it is actually management's responsibility to take the first step and initiate trusting relationships" (Whitener et al. $1998,514)$. In this regard, various leadership styles, such as transactional or transformational leadership (Mackenzie, Podsakoff, and Rich 2001) and ethical leadership (Schwepker 2019) have been investigated as antecedents of subordinates' trust in managers. The influence of a number of other managerial characteristics and behaviors, such as procedural and distributive justice (Flaherty and Pappas 2002), dependability, competence, and consideration (Schetzsle and Delpechitre 2013), opportunism, respect, and shared values (Brashear et al. 2003), control mechanisms (Brashear et al. 2005), and role-modeling (Rich 1997), have also been examined in the literature. Drawing from and extending this body of work, this study proposes that sales managers' leadership worthiness serves as an important antecedent of salespersons' trust in sales managers. That is, when sales managers are perceived as worthy leaders, they are more likely to be trusted by their subordinate salespersons.

Competence is a widely studied antecedent of trust in managers in both sales and non-sales settings (e.g., Liborius
2014; Mayer, Davis, and Schoorman 1995; Schetzsle and Delpechitre 2013). When managers are perceived as possessing knowledge, skills, and abilities in a particular area, they are more likely to be trusted pertaining to tasks in that area (Mayer, Davis, and Schoorman 1995). Therefore, competent managers are more likely to be approached for guidance and support, which enhance respect and trust toward the manager. Competent managers are also more likely to provide accurate information, issue appropriate explanations for their decisions and timely feedback, and exchange information through open communication. Such communication patterns, which are typically exhibited by knowledgeable and experienced managers, also enhance managers' trustworthiness (Whitener et al. 1998). The charisma dimension of leadership worthiness also enhances trust, since charismatic managers motivate followers by articulating a compelling vision and by role-modeling appropriate behaviors. Prior scholars (e.g., Conger, Kanungo, and Menon 2000) also note that charismatic managers transcend self-interest and demonstrate discernable concern for followers' needs, actions, and sacrifices. As Conger, Kanungo, and Menon (2000, 751) state, "In essence, charismatic leaders strive to demonstrate that they are indefatigable workers prepared to take on high personal risks or incur high personal costs in order to achieve their shared vision. Through such personal examples, the charismatic leader reinforces perceptions that he or she is worthy of complete trust."

Behavioral integrity has also been demonstrated to induce trust. When employees observe consistency across their manager's words and actions, they not only become more confident of the manager's future behavior, but also form inferences about the manager's honesty and moral character (Mayer, Davis, and Schoorman 1995; Whitener et al. 1998). These, in turn, reduce perceived risk and enhance willingness to be vulnerable with regard to the manager's actions and relationships with the manager. That is, attributions of behavioral integrity, which stem from assessment of past events, bear influence on the formation of trust, which governs future decisions (Simons 2002). Behavioral integrity also increases the credibility and perceived authenticity of the manager, which in turn, influence trust in the manager (Gardner, Fischer, and Hunt 2009). Given these arguments and prior findings, it is expected that the sales managers' leadership worthiness, composed of competence, charisma, and behavioral integrity dimensions, will enhance salespersons trust in sales managers. Hence:

$\mathbf{H}_{\mathbf{4}}$ : Sales managers' leadership worthiness positively influences salespersons' trust in sales managers.

Salespersons' trust in their manager is expected to decrease turnover intentions directly, as well as indirectly, through fostering identification with the manager. When subordinates trust their manager, they are likely to feel safer and more comfortable with the manager's guidance, actions, decisions. In turn, trust in managers can reduce psychological distress and increase job satisfaction, both of which reduce turnover intentions (Dirks and Ferrin 2002). Consistent with the postulate of social exchange theory (Blau 1964), trusting subordinates should be motivated to 
engage in recurrent exchanges with the manager and feel obligated to engage in reciprocal behavior. With trusted managers, salespersons are more likely to discuss workplace challenges opportunities and, potentially, even voluntary quitting intentions. Such communication pathways give sales managers the opportunity to intervene and implement any retention-oriented strategies, thereby curtailing turnover intentions. As such, prior research in leadership and sales has established the link between trust in managers and reduced turnover intentions (e.g., Colquitt, Scott, and LePine 2007; Costigan et al. 2011). In addition, trusted managers gain a positive reputation among subordinates, based on their impact on subordinates' self-confidence, well-being, and job performance (Mayer, Davis, and Schoorman 1995). Associations with trusted managers provide the opportunity for subordinates to satisfy the need for self-continuity (i.e., maintain a consistent sense of self), self-distinctiveness (i.e., distinguish from others in social contexts), and self-enhancement (i.e., enhance self-concept through associations) (Tajfel and Turner 1986), and such trusted managers become attractive targets for personal identification. As DeConinck (2011, 620) observes, "employees are more likely to form bonds that foster identification when they have trust in the organization and its leaders." Therefore, we propose:

$\mathbf{H}_{5}$ : Salespersons' trust in sales managers negatively influences turnover intentions.

$\mathbf{H}_{6}$ : Salespersons' trust in sales managers positively influences identification with sales managers.

\section{Moderating role of gratitude toward sales managers}

As noted earlier, managers are more effective based on inferences regarding "leaderlike" characteristics as well as attributions regarding past performance (Jacquart and Antonakis 2015). While managers' leadership worthiness can be a cue for influencing future performance, their contributions to past performance also warrant consideration for a holistic understanding of their overall effectiveness. As Eberly et al. (2011, 733) note, "Attributions are the causal explanations that individuals use to interpret the world around them and adapt to their environment." If salespersons deem that their manager has positively impacted their performance, they are essentially making an external-person attribution for their performance. As a result, feelings of gratitude, or emotional appreciation for the manager's contributions, are likely to develop (Palmatier et al. 2009). Specifically, gratitude is a positive emotion that "stems from the perception of a positive personal outcome, not necessarily deserved or earned, that is due to the actions of another person" (Emmons and McCullough 2003, 377). As Palmatier et al. $(2009,2)$ note, "Gratitude is a fundamental social component of human interactions that provides an emotional foundation for reciprocal behaviors." In recent years, marketing and sales researchers have acknowledged the importance of gratitude as a construct that enriches interpersonal relationships (Mangus et al. 2017; Pelser et al. 2015).
Correspondingly, gratitude has been explored as a moderator in frameworks of interpersonal relationships. Pelser et al. (2015), in the context of buyer-seller relationships, find that at higher levels gratitude buffers the negative effect of indebtedness on sales effort and commitment, while Badrinarayanan, Ramachandran, and Madhavaram (2019b) report that salespersons' gratitude toward sales managers enhances the relationship between sales manager's ethical leadership and salespersons' intentions to emulate ethical behaviors. Given that support from managers creates reciprocity norms and increases felt obligation to respond favorably (Eisenberger et al. 2001), this study proposes that salespersons' gratitude toward sales managers, which stems from an experience-based attribution of past performance to the manager, will negatively moderate the relationship between leadership worthiness and turnover intentions (i.e., leadership worthiness exerts a more negative effect on turnover intentions when gratitude is higher) as well as positively moderate the relationships between leadership worthiness and both identification with the manager and trust in the manager (i.e., leadership worthiness exerts a more positive effect on trust and identification when gratitude is higher).

The effect of leadership worthiness on turnover intentions is expected to be more negative at higher levels of gratitude, especially given that grateful employees experience a positive emotional state, which makes them more likely to build social bonds with others in the organization as well as engage in behaviors that benefit the organization (Sun, Liden, and Ouyang 2019). Sales managers' leadership worthiness, therefore, can more effectively lower turnover intentions when salespersons are entrenched in the organization through broad social connections and are invested in making positive contributions toward the organization. The effect of leadership worthiness on salespersons' trust in managers is expected to be stronger at higher levels of gratitude. Gratitude ensues when there is awareness that a benefit was provided without any ulterior motives (Pelser et al. 2015) and serves as an affective trigger for the formation of cognition-based trust (McAllister 1995). Salespersons' gratitude toward their managers creates "an ingrained psychological pressure" (Palmatier et al. 2009, 2) to reciprocate positively for their managers' contributions to their development and betterment (Badrinarayanan, Ramachandran, and Madhavaram 2019b). That is, the effect of leadership worthiness on trust is likely to be strengthened when salespersons are grateful and appreciative of the positive benefits derived from their manager's benevolent contributions to their performance.

Finally, the effect of leadership worthiness on salespersons' identification with managers is also expected to be stronger at higher levels of gratitude. Through leadership worthiness, managers create and maintain a positive relational climate that nurtures interpersonal closeness, which prompt personal identification by encouraging mutual selfdisclosure, shared activities, responsiveness, and mutual commitment (Ashforth, Schinoff, and Rogers 2016). The social effects of gratitude include the maintenance of 
Table 2. Descriptive statistics and inter-construct correlations.

\begin{tabular}{|c|c|c|c|c|c|c|c|c|c|c|c|c|c|c|}
\hline & Mean & SD & Alpha & CR & 1 & 2 & 3 & 4 & 5 & 6 & 7 & 8 & 9 & 10 \\
\hline 1. Manager Competence & 5.96 & 1.12 & .94 & .95 & .80 & & & & & & & & & \\
\hline 2. Manager Charisma & 5.18 & 1.28 & .91 & .94 & .23 & .87 & & & & & & & & \\
\hline 3. Manager Behavioral Integrity & 5.46 & 1.26 & .89 & .92 & .23 & .71 & .67 & & & & & & & \\
\hline 4. Trust in Managers & 5.38 & 1.36 & .92 & .95 & .23 & .66 & .79 & .87 & & & & & & \\
\hline 5. Identification with Managers & 4.40 & 1.29 & .86 & .88 & .30 & .59 & .66 & .72 & .61 & & & & & \\
\hline 6. Gratitude toward Manager & 5.07 & 1.51 & .86 & .87 & .79 & .25 & .23 & .22 & .28 & .68 & & & & \\
\hline 7. Turnover Intentions & 3.59 & 1.46 & .89 & .89 & -.26 & -.57 & -.38 & -.64 & -.73 & -.25 & .74 & & & \\
\hline 8. Salesperson Performance & 6.08 & 0.64 & .76 & .81 & .32 & .20 & .23 & .20 & .25 & .30 & -.22 & .68 & & \\
\hline 9. Sales Experience & - & - & - & - & .18 & -.09 & -.06 & -.15 & -.00 & .14 & -.13 & -.02 & - & \\
\hline 10. Experience under Manager & - & - & - & - & .10 & -.01 & .06 & .01 & .05 & .08 & -.01 & .12 & .26 & - \\
\hline
\end{tabular}

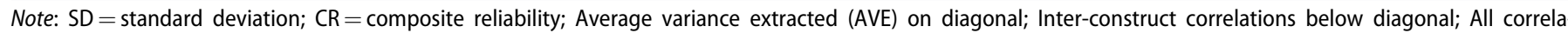
tions $>.15$ significant at $p<.05$.

existing close relationships and solidification of new ones (Pelser et al. 2015). Thus, gratitude toward sales managers is expected to augment the positive relationship between sales managers' leadership worthiness and salesperson's identification with the manager. Accordingly, we propose:

\footnotetext{
$\mathbf{H}_{7(\mathbf{a})}$ : Salespersons' gratitude toward sales managers negatively moderates the relationship between sales managers' leadership worthiness and salesperson turnover intentions.
}

\begin{abstract}
$\mathbf{H}_{7(\mathbf{b})}$ : Salespersons' gratitude toward sales managers positively moderates the relationship between sales managers' leadership worthiness and salespersons' identification with sales managers.
\end{abstract}

$\mathbf{H}_{7(\mathbf{c})}$ : Salespersons' gratitude toward sales managers positively moderates the relationship between sales managers' leadership worthiness and salespersons' trust in sales managers.

\section{Method}

\section{Data collection and measurement}

Data was collected using an online survey of business-tobusiness (B2B) salespeople drawn from a multi-industry salesforce panel maintained by a reputed research firm. This population was deemed appropriate for the study not only because B2B salespeople are highly influenced by their managers' actions, but also due to the high turnover rates and replacement costs plaguing the B2B salesforce (Hartmann, Rutherford, and Park 2017). The firm hosted the survey on its website and distributed it to qualified respondents. After filtering out respondents who failed attention filters, screening questions, and speeding checks, the firm delivered 271 complete and usable responses. To maintain objectivity, the removal of respondents was done by the research firm prior to the delivery of the dataset and without the involvement of the study's researchers (Babin, Griffin, and Hair 2016). About fifty-seven (forty-three) percent of the respondents were male (female) and the average age was reported as approximately 45 years.

Established measures, with multiple items and sevenpoint scales $(1=$ "Strongly Disagree" to $7=$ "Strongly Agree"), were used for all constructs in the proposed framework (see measures and items in Appendix). Consistent with our conceptualization, sales managers' leadership worthiness was operationalized as a second-order formative construct with its three first-order dimensions measured reflectively. The first dimension, sales manager competence, was measured using a four-item scale from Mayer and Davis (1999). The second dimension, sales manager charisma, was measured using a four-item scale drawn from the idealized influence component of the multifactor leadership questionnaire (MLQ; Bass and Avolio 1997). Finally, the third dimension, sales manager behavioral integrity, was measured using a four-item scale from Simons et al. (2007) that focuses on the enactment of espoused values.

With regard to the consequences of sales managers' leadership worthiness, salespersons' trust in sales managers was captured using a three-item scale from Mackenzie, Podsakoff, and Rich (2001), salespersons' identification with sales managers was measured using a four-item scale borrowed from Mael and Ashforth (1992), and salespersons' turnover intentions were measured using a three-item scale from Bluedorn (1982). The proposed moderating variable, gratitude toward sales managers was measured using a three-item scale adapted from Palmatier et al. (2009). As for the control variables, salesperson performance was measured using a scale from Miao and Evans (2007), while experience in sales and experience under sales manager were each measured with a single question (i.e., sales experience using "How many years have you worked in full-time sales positions?" and experience under manager using "How many years have you worked under your current manager?"). Descriptive statistics, construct properties, and inter-construct correlations are provided in Table 2.

\section{Preliminary analysis}

Data analysis were conducted using partial least squares structural equation modeling (PLS-SEM) with SmartPLS 3.0. The use of PLS-SEM was deemed appropriate for this study given that this analytical procedure: 1) supports the testing of theoretical frameworks from a prediction perspective (Hair et al. 2019), 2) enables easier testing of complex structural models with both first-order reflective and secondorder formative constructs as compared to covariance-based structural equation modeling (Hair et al. 2019), and 3) has been widely applied in several studies in the sales literature (e.g., Bolander et al. 2015; Kalra et al. 2017; Matthews et al. 2018).

Before testing the hypothesized relationships, the adequacy and psychometric properties of all reflective constructs were assessed following prescribed guidelines (Hair et al. 2019). Cronbach's alpha and composite reliabilities for 
Table 3. Results of hypotheses tests.

\begin{tabular}{|c|c|c|c|c|}
\hline Hypotheses & $\beta$ & T Statistic & P Value & Result \\
\hline \multicolumn{5}{|l|}{ Direct Effects } \\
\hline $\mathrm{H}_{1}$ : Leadership Worthiness - Turnover Intentions & -.17 & 2.32 & .01 & Supported \\
\hline $\mathrm{H}_{2}$ : Leadership Worthiness - Identification & .28 & 4.26 & .00 & Supported \\
\hline $\mathrm{H}_{3}$ : Identification - Turnover Intentions & -.60 & 10.44 & .00 & Supported \\
\hline $\mathrm{H}_{4}$ : Leadership Worthiness - Trust & .79 & 20.74 & .00 & Supported \\
\hline $\mathrm{H}_{5}:$ Trust - Turnover Intentions & .04 & 0.57 & .28 & Not Supported \\
\hline $\mathrm{H}_{6}:$ Trust - Identification & .50 & 7.73 & .00 & Supported \\
\hline \multicolumn{5}{|l|}{ Moderating Effects } \\
\hline $\mathrm{H}_{7 \mathrm{a}}$ : Leadership Worthiness $*$ Gratitude - Turnover Intentions & -.09 & 2.75 & .02 & Supported \\
\hline $\mathrm{H}_{7 \mathrm{~b}}$ : Leadership Worthiness * Gratitude - Identification & .06 & 2.12 & .02 & Supported \\
\hline $\mathrm{H}_{7 \mathrm{c}}:$ Leadership Worthiness $*$ Gratitude - Trust & .01 & 0.33 & .36 & Not Supported \\
\hline
\end{tabular}

each construct exceeded .80 . These results provide evidence for reliability of the chosen reflective constructs. Further, all items showed strong and significant loading on their respective constructs with factor loadings exceeding 0.60 (significant at $\alpha=.01$ ), thus providing support for convergent validity of measures. The average variance extracted (AVE) values for each construct exceeded the prescribed cutoff of 0.50 and was greater than the square of all interconstruct correlations involving that construct, thus providing support for discriminant validity. As an additional test for discriminant validity, the heterotrait-monotrait (HTMT) ratio of average correlations of indicators across constructs was evaluated and found to be below the recommended cutoff of 0.90 (Henseler, Ringle, and Sarstedt 2015).

Common method variance was analyzed using Harman's one factor test and, as the factor solution revealed that no single factor accounts for a majority of the variance explained in the measurement items (Fuller et al. 2016), it was concluded that common method variance is unlikely to bias the results. Nonresponse bias was tested by comparing early respondents with late respondents (Armstrong and Overton 1977) and no significant differences were found on sample characteristics, as well as, the focal construct measures, thereby eliminating concerns about nonresponse bias. As sales manager's leadership worthiness is a second-order formative construct with three first-order reflective dimensions (i.e., competence, charisma, and behavioral integrity), the adequacy of the higher-order construct was assessed (Hair, Ringle, and Sarstedt 2011). The variance inflation factor (VIF) score for each of the three dimensions was below 3 and all three dimensions were significant predictors of the formative construct (competence: $\mathrm{b}$ $=.40, \mathrm{p}<.01$; charisma: $\mathrm{b}=.36, \mathrm{p}<.01$; and, behavioral integrity: $\mathrm{b}=.32, \mathrm{p}<.01$ ).

\section{Results of hypotheses tests}

The proposed hypotheses were tested using SmartPLS 3.0 with 5000 bootstrapping runs. Overall, the results for the structural model analysis provide support for seven of the nine hypotheses (see Table 3). Sales managers' leadership worthiness was found to be negatively related to turnover intentions $(\beta=-.17 ; \mathrm{p}<.01)$, supporting $\mathrm{H}_{1}$. Further, leadership worthiness was found to be positively related to identification with managers $(\beta=.28$; $\mathrm{p}<.01)$, while identification with managers was found to be negatively related to turnover intentions $(\beta=-.60 ; \mathrm{p}<.01)$. Thus, $\mathrm{H}_{2}$ and $\mathrm{H}_{3}$ were supported. Similarly, leadership worthiness was found to be positively related to trust in managers $(\beta=.79$; $\mathrm{p}<.01$ ), while the proposed negative relationship between trust in managers and turnover intentions was not supported. That is, $\mathrm{H}_{4}$ is supported but $\mathrm{H}_{5}$ is not supported. Trust in managers was found to be positively related to identification with managers $(\beta=.50 ; \mathrm{p}<.01)$, thus supporting $\mathrm{H}_{6}$. As further evidence of the explanatory power of the model, $\mathrm{R}^{2}$ and $\mathrm{Q}^{2}$ values were examined. The $\mathrm{R}^{2}$ and $\mathrm{Q}^{2}$ values, respectively, for turnover intentions $(76.8 \%, \mathrm{p}<.01$; $.69)$, identification $(56.8 \%, \mathrm{p}<.01 ; .36)$, and trust $(63.6 \% \mathrm{p}$ $<.01$; .52) suggest that the model has high predictive relevance (Hair, Ringle, and Sarstedt 2011).

To test the moderation hypotheses, the product indicator approach built in SmartPLS was employed. Gratitude was found to negatively moderate the relationship between sales managers' leadership worthiness and turnover intentions $(\beta$ $=-.09 ; \mathrm{p}<.05)$ as well as positively moderate the relationship between sales managers' leadership worthiness and identification with managers $(\beta=.06 ; \mathrm{p}<.05)$. However, the proposed moderating effect of gratitude on the relationship between sales managers' leadership worthiness and trust in managers was not supported. That is, while $\mathrm{H}_{7 \mathrm{a}}$ and $\mathrm{H}_{7 \mathrm{~b}}$ were supported, $\mathrm{H}_{7 \mathrm{c}}$ was not. The first moderation result indicates that the negative relationship between leadership worthiness and turnover intentions become more (less) negative at higher (lower) levels of gratitude toward manager. The second moderation result indicates that the positive relationship between leadership worthiness and identification with managers is more (less) positive at greater (lower) levels of gratitude toward manager. The results from the moderation tests are depicted graphically in Figure 2.

\section{Discussion and implications}

Drawing from and extending research in both leadership and sales literature (e.g., Brashear et al. 2003; DeConinck 2011), this study focuses on salespersons' perceptions regarding sales managers' leadership worthiness and examines its impact and contingent effects on salespersons' turnover intentions. Building on prior research on the role of sales managers in influencing salespersons' job-related attitudes and behaviors (Shanahan and Hopkins 2019), our results demonstrate that sales managers' leadership 


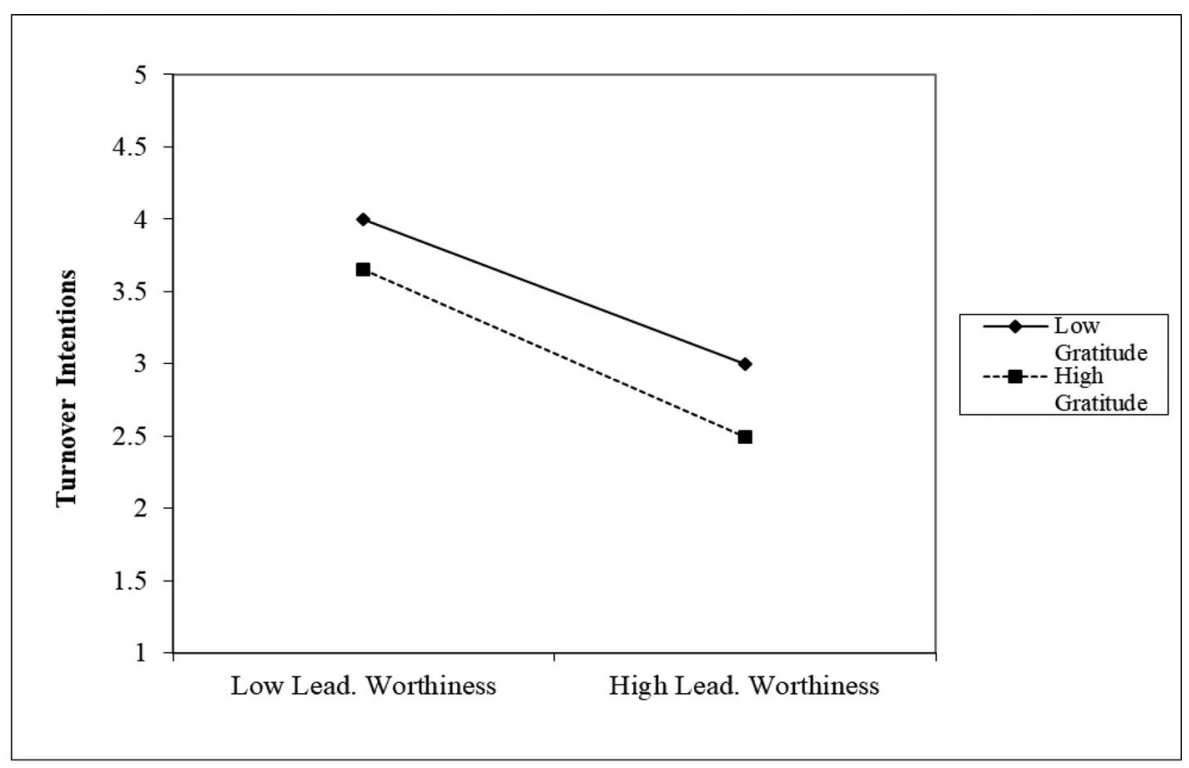

(a)

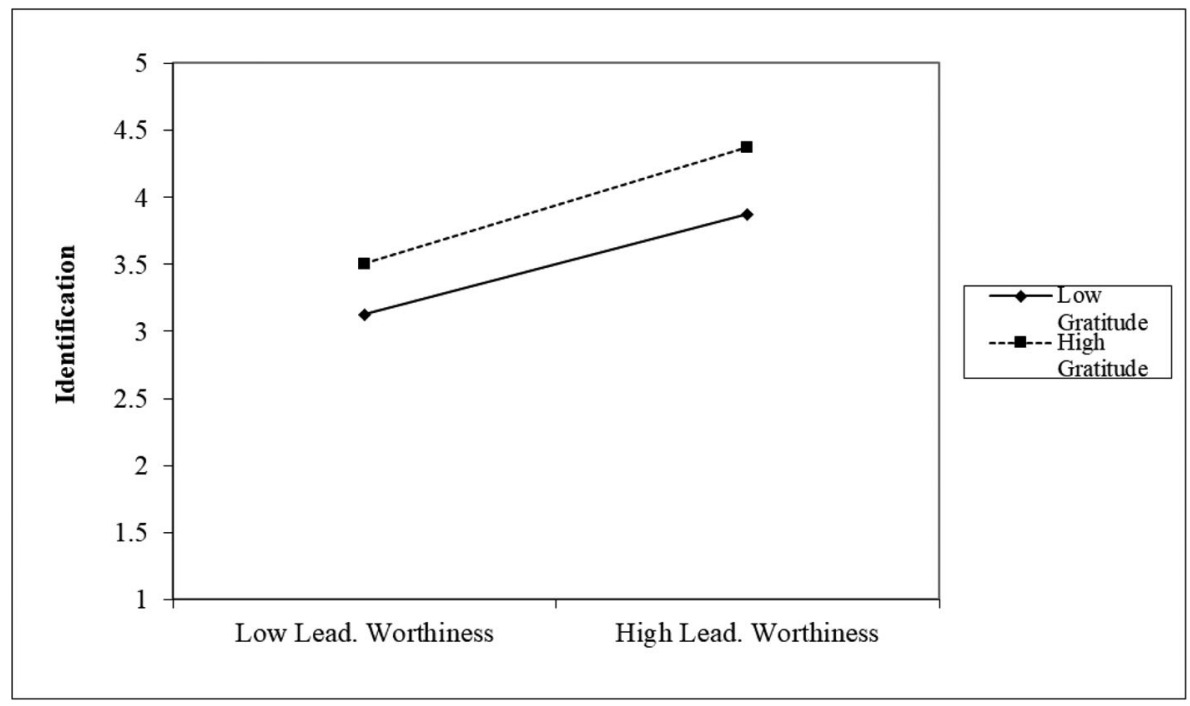

(b)

Figure 2. Moderating effect of gratitude. a) Sales managers' leadership worthiness * gratitude on turnover intentions; b) Sales managers' leadership worthiness * gratitude on identification.

worthiness serves as a "pull-to-stay" force and curbs salesperson turnover intentions both directly and indirectly through cultivating trust in managers and personal identification with managers. Thus, when sales managers are perceived to possess desirable leadership qualities of competence, charisma, and behavioral integrity, they are more likely to reduce salespersons' turnover intentions, win their trust, and build personal identification with them. Personal identification with sales managers was found to be negatively related to turnover intentions, further solidifying extant knowledge on the importance of identification as a deep psychological connection that binds individuals together. Interestingly, while trust in a sales manager was positively related to identification with the manager as expected, it did not exert a significant direct relationship on turnover intentions. Indeed, some prior studies have reported that that trust in immediate supervisors is less powerful than trust in senior management in reducing turnover intentions (Costigan et al. 2011), while others have found that trust in immediate managers exerts an indirect effect on turnover intentions through variables such as organizational identification (DeConinck 2011) and organization commitment (Brashear et al. 2003). The current study adds to this body of knowledge by suggesting that cognitive trust in managers alone may not be a sufficient condition for tempering turnover intentions, but that trust beliefs become important in forging personal identification with managers and, subsequently, reduce turnover intentions. Additionally, the results show that the effect of leadership worthiness is boosted by salespersons' gratitude toward sales managers. In particular, we find that salespersons with higher levels of positive emotions stemming from attribution 
of performance to their managers respond to sales managers' leadership worthiness with even lower levels of turnover intentions and even higher levels of personal identification with the manager. However, the proposed effect on trust in managers was not supported.

This study offers several contributions to sales research and practice. First, by drawing attention to the construct of sales managers' leadership worthiness, this study integrates recent advances in leadership research within the sales context and draws attention to the ramifications of salespersons' perceptions of sales leadership. While recent sales research has identified key sales leader behaviors (Peesker et al. 2019), there has been little systematic research on salespersons' perceptions about whether their managers possess requisite qualities to be deemed worthy leaders. The construct of leadership worthiness, conceptualized as salespersons' perceptions regarding the extent to which sales managers possess appropriate contextual skills and abilities, exert idealized influence, and demonstrate behavioral integrity, provides a novel theoretical perspective into how sales managers can develop stronger and meaningful relational ties with salespersons and reduce their turnover intentions that is, exert a "pull-to-stay" effect. To be clear, leadership worthiness is not an arbitrary amalgamation of three leader characteristics. Instead, consistent with theoretical advances in leadership research, it captures important sales leadership dimensions that must be projected for salespeople to admire, respect, and follow their managers.

The focus on sales managers' leadership worthiness also contributes to the rapidly evolving body of knowledge on the role of mid-level sales managers (e.g., Badrinarayanan, Ramachandran, and Madhavaram 2019a; Guenzi et al. 2019; Skiba, Saini, and Friend 2019) and responds to calls for better delineation of salespersons' perceptions of leadership characteristics of such managers (Plank et al. 2018). In addition, our operationalization of leadership worthiness as a higher-order formative construct consisting of three firstorder reflective dimensions: competence, charisma, and behavioral integrity, complements prior approaches on sales leader characteristics (Peesker et al. 2019), worthy leadership (Thompson et al. 2008), and leader's worthiness of being followed (Liborius 2014). From a managerial standpoint, leadership worthiness dimensions can serve as a useful guideline in not only hiring, training, and evaluating sales managers, but also in assessing congruency in sales manager and salesperson perceptions during performance appraisal and feedback processes. In particular, such evaluations can be employed as part of 360-degree evaluation programs and can allow salespersons to feel that they have a voice in the process, thereby leading to increased involvement and engagement.

Second, this study also extends current knowledge on salesperson turnover intentions. Although prior research on sales force turnover has examined the attenuating effects of leadership styles (e.g., Jaramillo et al. 2009), leader-member exchange (Darrat, Atinc, and Babin 2016), and managerial characteristics (e.g., Brashear et al. 2003; Jones et al. 1996), the examination of leadership worthiness and personal identification as antecedents represent novel contributions. In particular, personal identification - a construct that is different from social identification or relational identification (Ashforth, Schinoff, and Rogers 2016) - has received little attention in the sales literature (Ahearne et al. 2013), especially as an antecedent of turnover intentions. Sales organizations can monitor salespersons' perceptions of leadership worthiness and personal identification and use them as barometers for forecasting potential attrition rates.

Third, by testing the moderating role of gratitude, we offer additional nuance on current understanding of the relationship between of leadership characteristics and salesperson outcomes. Although gratitude is an important relational variable pertaining to salespersons and other boundary-spanners (Mangus et al. 2017; Palmatier et al. 2009), the construct has not yet been investigated in the context of salesperson-manager relationships. Therefore, by focusing on salespersons' gratitude toward their managers and demonstrating that gratitude based on performance attributions enhances the impact of leadership worthiness on salesperson outcomes, this study not only expands the boundaries of the gratitude literature but also adds to the limited evidence on gratitude as a moderating variable (Pelser et al. 2015). Sales organizations can trigger salespersons' gratitude toward sales managers through gratitude interventions, where salespersons can reflect on what they are grateful for (Mangus et al. 2017). Supplementing such interventions, sales organizations can also institute periodic developmental feedback protocols, where sales managers provide salespersons with future-oriented information and guidance for personal improvement (Fehr et al. 2017). When such developmental feedback involves efforts toward discussing current progress, skill development, and identifying growth trajectories, it can play a key role in engendering gratitude (Fehr et al. 2017).

\section{Limitations and avenues for future research}

We acknowledge limitations and potential avenues for future extensions inherent in our research. Our study uses crosssectional survey data and suffers from typical limitations associated with this methodology. First, our data represents a snapshot in time and might mask important insights that may be derived from a longitudinal approach using data from multiple time-periods. While managerial characteristics associated with leadership worthiness might be impactful at a given time, perceptions regarding such characteristics and their resultant impact might evolve over time. Using a longitudinal approach, scholars can pursue dynamics in the influence of leadership characteristics on turnover intentions and also uncover potential trigger events that lend greater sophistication toward interpreting the results. Second, as the use of single-informant data from salespersons alone can lead to biased results, future research can improve upon this study by collecting dyadic or nested data, supplemented by appropriate objective measures of actual turnover. We encourage future researchers to consider multi-level, multisource data using a nested structure of sales managers and salespeople to build on this study. 
The construct of leadership worthiness represents multiple potential avenues for future sales research. Consistent with the objectives of this study, we focused only on the nature and consequences of leadership worthiness. However, future studies can draw from prior leadership and sales research to identify the antecedents of leadership worthiness. Toward this end, it would be interesting, from a followership theory perspective (Uhl-Bien et al. 2014), to unearth specific salesperson traits, motivations, and behaviors that induce them to construct perceptions of leadership worthiness. In addition, manager-related antecedents, such as manager prototypicality and leadership styles, as well as organizational antecedents, such as culture and ethical climate, can be investigated as antecedents of leadership worthiness. Also, similarity between salesperson and sales manager gender, age, and other traits can shed some light on whether homophily plays a role in evaluation of leadership worthiness and its outcomes. Furthermore, other consequences of leadership worthiness, such as customer engagement, salesperson performance, and prosocial behaviors, merit future inquiry. Finally, researchers can also investigate various salesperson, peer, manager, work design, organizational, and environmental characteristics as moderators of the influence of leadership worthiness on desired outcomes. In particular, it would be worthwhile to explore whether leadership worthiness can help in maintaining salespeople morale and effectiveness during sudden exogenous shocks to the sales environment, such as the one brought about by the COVID-19 pandemic. Overall, future research could offer a more holistic understanding of how leadership worthiness forms and who is more likely to perceive it as well as on how it affects and is affected by various factors idiosyncratic to the sales organization.

Another fruitful avenue of research could involve exploring the "dark-side" or negative consequences of leadership worthiness. As our results depict, leadership worthiness operates partially through identification, and thus begs the question: can leadership worthiness lead to over-identification with a manager which may have negative consequences for the organization? (e.g., Ahearne et al. 2013). Along similar lines, it would be interesting to study whether the departure of managers who are perceived as worthy leaders causes turnover contagion, where several subordinates also leave subsequently. Whereas our study is limited to leadership worthiness at the immediate manager level, salespersons are impacted by leadership at different organizational levels and functional units. Therefore, it would be further illuminating to examine perceptions of leadership worthiness at the corporate level, such as top marketing and sales executives (Wang, Gupta, and Grewal 2017) as well as across different functional units that salespersons interface with. Finally, it would be informative to examine the robustness of leadership worthiness across different cultural and national settings. In short, we hope that our study paves the way for more research on this important and promising area for sales theory and practice.

\section{Declaration of interest}

No potential conflict of interest was reported by the authors.

\section{References}

Ahearne, Michael, Till Haumann, Florian Kraus, and Jan Wieseke. 2013. "It's a Matter of Congruence: How Interpersonal Identification between Sales Managers and Salespersons Shapes Sales Success." Journal of the Academy of Marketing Science 41 (6):625-48. doi: 10. 1007/s11747-013-0333-x.

Armstrong, J. S., and Terry S. Overton. 1977. "Estimating Nonresponse Bias in Mail Surveys." Journal of Marketing Research 14 (3):396-402. doi: $10.2307 / 3150783$.

Ashforth, Blake E., Beth S. Schinoff, and Kristie M. Rogers. 2016. "I Identify with Her,' 'I Identify with Him': Unpacking the Dynamics of Personal Identification in Organizations." Academy of Management Review 41 (1):28-60. doi: 10.5465/amr.2014.0033.

Avolio, Bruce J., Fred O. Walumbwa, and Todd J. Weber. 2009. "Leadership: Current Theories, Research, and Future Directions." Annual Review of Psychology 60 (1):421-49. doi: 10.1146/annurev. psych.60.110707.163621.

Babin, Barry J., Mitch Griffin, and Joseph F. Hair. Jr. 2016. "Heresies and Sacred Cows in Scholarly Marketing Publications." Journal of Business Research 69 (8):3133-8. doi: 10.1016/j.jbusres.2015.12.001.

Badrinarayanan, Vishag, Indu Ramachandran, and Sreedhar Madhavaram. 2019a. "Resource Orchestration and Dynamic Managerial Capabilities: Focusing on Sales Managers as Effective Resource Orchestrators." Journal of Personal Selling \& Sales Management 39 (1):23-41. doi: 10.1080/08853134.2018.1466308.

Badrinarayanan, Vishag, Indu Ramachandran, and Sreedhar Madhavaram. 2019b. "Mirroring the Boss: Ethical Leadership, Emulation Intentions, and Salesperson Performance." Journal of Business Ethics 159 (3):897-912. doi: 10.1007/s10551-018-3842-1.

Baer, Markus, and Michael Frese. 2003. "Innovation is Not Enough: Climates for Initiative and Psychological Safety, Process Innovations, and Firm Performance." Journal of Organizational Behavior 24 (1): 45-68. doi: 10.1002/job.179.

Bass, Bernard M., and Bruce J. Avolio. 1997. Full-Range of Leadership Development: Manual for the Multifactor Leadership Questionnaire. Palo Alto, CA: Mind Garden.

Blau, Peter M. 1964. Exchange and Power in Social Life. New York: Wiley.

Bluedorn, Allen C. 1982. "A Unified Model of Turnover from Organizations.” Human Relations 35 (2):135-53. doi: 10.1177/ 001872678203500204.

Bolander, Willy, Cinthia B. Satornino, Douglas E. Hughes, and Gerald R. Ferris. 2015. "Social Networks within Sales Organizations: Their Development and Importance for Salesperson Performance." Journal of Marketing 79 (6):1-16. doi: 10.1509/jm.14.0444.

Boles, James S., George W. Dudley, Vincent Onyemah, Dominique Rouziès, and William A. Weeks. 2012. "Sales Force Turnover and Retention: A Research Agenda." Journal of Personal Selling \& Sales Management 32 (1):131-40. doi: 10.2753/PSS0885-3134320111.

Brashear, Thomas G., Chris Manolis, and Charles M. Brooks. 2005. "The Effects of Control, Trust, and Justice on Salesperson Turnover." Journal of Business Research 58 (3):241-9. doi: 10.1016/ S0148-2963(03)00134-6.

Brashear, Thomas G., James S. Boles, Danny N. Bellenger, and Charles M. Brooks. 2003. "An Empirical Test of Trust-Building Processes and Outcomes in Sales Manager-Salesperson Relationships." Journal of the Academy of Marketing Science 31 (2): 189-200. doi: 10.1177/0092070302250902.

Chaker, Nawar N., Doug Walker, Edward L. Nowlin, and Nwamaka A. Anaza. 2019. "When and How Does Sales Manager Physical Attractiveness Impact Credibility: A Test of Two Competing Hypotheses." Journal of Business Research 105:98-108. doi: 10.1016/j. jbusres.2019.08.004.

Chun, Jae Uk, Francis J. Yammarino, Shelley D. Dionne, John J. Sosik, and Hyoung Koo Moon. 2009. "Leadership across Hierarchical Levels: Multiple Levels of Management and Multiple Levels of Analysis." The Leadership Quarterly 20 (5):689-707. doi: 10.1016/j. leaqua.2009.06.003. 
Colquitt, Jason A., Brent A. Scott, and Jeffery A. LePine. 2007. "Trust, Trustworthiness, and Trust Propensity: A Meta-Analytic Test of Their Unique Relationships with Risk Taking and Job Performance." The Journal of Applied Psychology 92 (4):909-27. doi: 10.1037/00219010.92.4.909.

Comaford, Christine. 2016. "Salespeople Are Burning Out Faster Than Ever-Here's Why.” Forbes. Accessed March 1, 2020. https://www. forbes.com/sites/christinecomaford/2016/06/18/how-leaders-canengage-retain-top-sales-talent.

Conger, Jay A., Rabindra N. Kanungo, and Sanjay T. Menon. 2000. "Charismatic Leadership and Follower Effects." Journal of Organizational Behavior 21 (7):747-67. doi: 10.1002/10991379(200011)21:7 < 747::AID-JOB46 > 3.0.CO;2-J.

Costigan, Robert D., Richard C. Insinga, J. J. Berman, Grazyna Kranas, and Vladimir A. Kureshov. 2011. "Revisiting the Relationship of Supervisor Trust and CEO Trust to Turnover Intentions: A ThreeCountry Comparative Study." Journal of World Business 46 (1): 74-83. doi: 10.1016/j.jwb.2010.05.019.

Darmon, René Y. 2008. "The Concept of Salesperson Replacement Value: A Sales Force Turnover Management Tool." Journal of Personal Selling \& Sales Management 28 (3):211-32. doi: 10.2753/ PSS0885-3134280301.

Darrat, Mahmoud, Guclu Atinc, and Barry J. Babin. 2016. "On the Dysfunctional Consequences of Salesperson Exhaustion." Journal of Marketing Theory and Practice 24 (2):236-45. doi: 10.1080/ 10696679.2016.1130563.

Davis, Anne L., and Hannah Rothstein. 2006. "The Effects of the Perceived Behavioral Integrity of Managers on Employee Attitudes: A Meta-Analysis." Journal of Business Ethics 67 (4):407-19. doi: 10. 1007/s10551-006-9034-4.

DeConinck, James B. 2011. "The Effects of Leader-Member Exchange and Organizational Identification on Performance and Turnover among Salespeople." Journal of Personal Selling \& Sales Management 31 (1):21-34. doi: 10.2753/PSS0885-3134310102.

Dirks, Kurt T., and Donald L. Ferrin. 2002. "Trust in Leadership: Meta-Analytic Findings and Implications for Research and Practice." The Journal of Applied Psychology 87 (4):611-28. doi: 10.1037/00219010.87.4.611.

Eberly, Marion B., Erica C. Holley, Michael D. Johnson, and Terence R. Mitchell. 2011. "Beyond Internal and External: A Dyadic Theory of Relational Attributions." Academy of Management Review 36 (4):731-53. doi: 10.5465/amr.2009.0371.

Eisenberger, R., S. Armeli, B. Rexwinkel, P. D. Lynch, and L. Rhoades. 2001. "Reciprocation of Perceived Organizational Support." The Journal of Applied Psychology 86 (1):42-51. doi: 10.1037/0021-9010. 86.1.42.

Emmons, Robert A., and Michael E. McCullough. 2003. "Counting Blessings versus Burdens: An Experimental Investigation of Gratitude and Subjective Well-Being in Daily Life." Journal of Personality and Social Psychology 84 (2):377-89. doi:10.1037/00223514.84.2.377.

Fanelli, Angelo, and Vilmos F. Misangyi. 2006. "Bringing out Charisma: CEO Charisma and External Stakeholders." Academy of Management Review 31 (4):1049-61. doi: 10.5465/amr.2006. 22528170 .

Fang, Eric (Er), Robert W. Palmatier, Lisa K. Scheer, and Ning Li. 2008. "Trust at Different Organizational Levels." Journal of Marketing 72 (2):80-98. doi: 10.1509/jmkg.72.2.80.

Fehr, Ryan, Ashley Fulmer, Eli Awtrey, and Jared A. Miller. 2017. "The Grateful Workplace: A Multilevel Model of Gratitude in Organizations." Academy of Management Review 42 (2):361-81. doi: 10.5465/amr.2014.0374.

Flaherty, Karen, K., and James M. Pappas. 2000. "The Role of Trust in Salesperson - Sales Manager Relationships." Journal of Personal Selling \& Sales Management 20 (4):271-8. doi: 10.1080/08853134. 2000.10754247

Flaherty, Karen E., and James M. Pappas. 2002. "Using Career Stage Theory to Predict Turnover Intentions among Salespeople." Journal of Marketing Theory and Practice 10 (3):48-57. doi: 10.1080/ 10696679.2002.11501919.
Fuchs, Sebastian. 2011. "The Impact of Manager and Top Management Identification on the Relationship between Perceived Organizational Justice and Change-Oriented Behavior." Leadership \& Organization Development Journal 32 (6):555-83. doi: 10.1108/ 01437731111161067.

Fuller, Christie M., Marcia J. Simmering, Guclu Atinc, Yasemin Atinc, and Barry J. Babin. 2016. "Common Methods Variance Detection in Business." Journal of Business Research 69 (8):3192-1202. doi: 10 1016/j.jbusres.2015.12.008.

Gallup. 2019. “This Fixable Problem Costs U.S. Businesses \$1 Trillion." Gallup Workplace Report. Accessed March 01, 2020. https://www. gallup.com/workplace/247391/fixable-problem-costs-businesses-trillion.aspx.

Gardner, William L., and Bruce J. Avolio. 1998. "The Charismatic Relationship: A Dramaturgical Perspective." Academy of Management Review 23 (1):32-58. doi: 10.5465/amr.1998.192958.

Gardner, William L., Dawn Fischer, and James G. (Jerry). Hunt. 2009. "Emotional Labor and Leadership: A Threat to Authenticity?" The Leadership Quarterly 20 (3):466-82. doi: 10.1016/j.leaqua.2009.03. 011.

Grisaffe, Douglas B., and Fernando Jaramillo. 2007. "Toward Higher Levels of Ethics: Preliminary Evidence of Positive Outcomes." Journal of Personal Selling \& Sales Management 27 (4):355-71. doi: 10.2753/PSS0885-3134270406.

Guenzi, Paolo, Deva Rangarajan, Nawar N. Chaker, and Laszlo Sajtos. 2019. "It is All in Good Humor? Examining the Impact of Salesperson Evaluations of Leader Humor on Salesperson Job Satisfaction and Job Stress." Journal of Personal Selling \& Sales Management 39 (4):352-69. doi: 10.1080/08853134.2019.1598267.

Gupta, Aditya, Alok Kumar, Rajdeep Grewal, and Gary L. Lilien. 2019. "Within-Seller and Buyer-Seller Network Structures and Key Account Profitability." Journal of Marketing 83 (1):108-32. doi: 10. $1177 / 0022242918812056$

Hair, Joseph F., Christian M. Ringle, and Marko Sarstedt. 2011. "PLSSEM: Indeed a Silver Bullet." Journal of Marketing Theory and Practice 19 (2):139-52. doi: 10.2753/MTP1069-6679190202.

Hair, Joseph F., Jeffrey J. Risher, Marko Sarstedt, and Christian M. Ringle. 2019. "When to Use and How to Report the Results of PLSSEM." European Business Review 31 (1):2-24. doi: 10.1108/EBR-112018-0203.

Halpert, Jane A. 1990. "The Dimensionality of Charisma." Journal of Business and Psychology 4 (4):399-410. doi: 10.1007/BF01013603.

Harris, Kenneth J., K. Michele Kacmar, and L. A. Witt. 2005. "An Examination of the Curvilinear Relationship between Leader-Member Exchange and Intent to Turnover." Journal of Organizational Behavior 26 (4):363-78. doi: 10.1002/job.314.

Hartmann, Nathaniel N., Brian N. Rutherford, and Jung Kun Park. 2017. "Sequencing of Multi-Faceted Job Satisfaction across Businessto-Business and Business-to-Consumer Salespeople: A Multi-Group Analysis." Journal of Business Research 70:153-9. doi: 10.1016/j. jbusres.2016.08.024.

Hartmann, Nathaniel N., Heiko Wieland, and Stephen L. Vargo. 2018. "Converging on a New Theoretical Foundation for Selling." Journal of Marketing 82 (2):1-18. doi: 10.1509/jm.16.0268.

Henseler, Jö, Christian Ringle, and Marko Sarstedt. 2015. “A New Criterion for Assessing Discriminant Validity in Variance-Based Structural Equation Modeling." Journal of the Academy of Marketing Science 43 (1):115-35. doi: 10.1007/s11747-014-0403-8.

Hwang, Alvin, Naresh Khatri, and E. S. Srinivas. 2005. "Organizational Charisma and Vision across Three Countries." Management Decision 43 (7-8):960-74. doi: 10.1108/00251740510609965.

Ingram, Thomas N., Raymond W. LaForge, William B. Locander, Scott B. MacKenzie, and Philip M. Podsakoff. 2005. "New Directions in Sales Leadership Research." Journal of Personal Selling \& Sales Management 25 (2):137-54. doi: 10.1080/08853134.2005. 10749055.

Jacquart, Philippe, and John Antonakis. 2015. "When Does Charisma Matter for Top-Level Leaders? Effect of Attributional Ambiguity." Academy of Management Journal 58 (4):1051-74. doi: 10.5465/amj. 2012.0831 
Jaramillo, Fernando, Douglas B. Grisaffe, Lawrence B. Chonko, and James A. Roberts. 2009. "Examining the Impact of Servant Leadership on Salesperson's Turnover Intention." Journal of Personal Selling \& Sales Management 29 (4):351-65. doi: 10.2753/ PSS0885-3134290404.

Jaramillo, Fernando, Jay Prakash Mulki, and James S. Boles. 2013. "Bringing Meaning to the Sales Job: The Effect of Ethical Climate and Customer Demandingness." Journal of Business Research 66 (11):2301-7. doi: 10.1016/j.jbusres.2012.03.013.

Johnston, Mark W., A. Parasuraman, Charles M. Futrell, and William C. Black. 1990. "A Longitudinal Assessment of the Impact of Selected Organizational Influences on Salespeople's Organizational Commitment during Early Employment." Journal of Marketing Research 27 (3):333-44. doi: 10.1016/0148-2963(89)90022-2.

Jones, Eli, Donna Massey Kantak, Charles M. Futrell, and Mark W. Johnston. 1996. "Leader Behavior, Work-Attitudes, and Turnover of Salespeople: An Integrative Study." Journal of Personal Selling \& Sales Management 16 (2):13-23. doi: 10.1080/08853134.1996. 10754050 .

Jones, Eli, Lawrence Chonko, Deva Rangarajan, and James Roberts. 2007. "The Role of Overload on Job Attitudes, Turnover Intentions, and Salesperson Performance." Journal of Business Research 60 (7): 663-71. doi: 10.1016/j.jbusres.2007.02.014.

Kalra, Ashish, Raj Agnihotri, Nawar N. Chaker, Rakesh K. Singh, and Barttanu Kumar Das. 2017. "Connect Within to Connect Outside: Effect of Salespeople's Political Skill on Relationship Performance." Journal of Personal Selling \& Sales Management 37 (4):332-48. doi: 10.1080/08853134.2017.1391100.

Kudisch, Jeffrey D., Mark L. Poteet, Gregory H. Dobbins, Michael C. Rush, and Joyce E. A. Russell. 1995. "Expert Power, Referent Power, and Charisma: Toward the Resolution of a Theoretical Debate." Journal of Business and Psychology 10 (2):177-95. doi: 10.1007/ BF02249578.

Lewin, Jeffrey E., and Jeffrey K. Sager. 2010. "The Influence of Personal Characteristics and Coping Strategies on Salespersons' Turnover Intentions." Journal of Personal Selling \& Sales Management 30 (4): 355-70. doi: 10.2753/PSS0885-3134300405.

Liborius, Patrick. 2014. "Who is Worthy of Being Followed? The Impact of Leaders' Character and the Moderating Role of Followers' Personality." The Journal of Psychology 148 (3):347-85. doi: 10.1080/ 00223980.2013 .801335

Lord, Robert G., and George M. Alliger. 1985. "A Comparison of Four Information Processing Models of Leadership and Social Perceptions." Human Relations 38 (1):47-65. doi: 10.1177/ 001872678503800103.

Mackenzie, Scott B., Philip M. Podsakoff, and Gregory A. Rich. 2001. "Transformational and Transactional Leadership and Salesperson Performance." Journal of the Academy of Marketing Science 29 (2): 115-34. doi: 10.1177/03079459994506.

Mael, Fred, and Blake E. Ashforth. 1992. "Alumni and Their Alma Mater: A Partial Test of the Reformulated Model of Organizational Identification." Journal of Organizational Behavior 13 (2):103-23. doi: 10.1002/job.4030130202.

Mangus, Stephanie M., Dora E. Bock, Eli Jones, and Judith Anne Garretson Folse. 2017. "Gratitude in Buyer-Seller Relationships: A Dyadic Investigation." Journal of Personal Selling \& Sales Management 37 (3):250-67. doi: 10.1080/08853134.2017.1352447.

Matthews, Lucy, Lisa Beeler, Alex R. Zablah, and Joe F. Hair. 2018. "All Autonomy is Not Created Equal: The Countervailing Effects of Salesperson Autonomy on Burnout." Journal of Personal Selling \& Sales Management 38 (3):303-22. doi: 10.1080/08853134.2017. 1398658.

Mayer, Roger C., and James H. Davis. 1999. "The Effect of the Performance Appraisal System on Trust for Management: A Field Quasi-Experiment.” Journal of Applied Psychology 84 (1):123-36. doi: 10.1037/0021-9010.84.1.123.

Mayer, Roger C., James H. Davis, and F. D. Schoorman. 1995. "An Integrative Model of Organizational Trust." Academy of Management Review 20 (3):709-34. doi: 10.5465/amr.1995. 9508080335
McAllister, Daniel J. 1995. "Affect- and Cognition-Based Trust as Foundations for Interpersonal Cooperation in Organizations." Academy of Management Journal 38 (1):24-59. doi: 10.2307/256727.

Miao, C. F., and Kenneth R. Evans. 2007. "The Impact of Salesperson Motivation on Role Perceptions and Job Performance-A Cognitive and Affective Perspective." Journal of Personal Selling \& Sales Management 27 (1):89-101. doi: 10.2753/PSS0885-3134270106.

Miao, Qing, Alexander Newman, and Peter Lamb. 2012. "Transformational Leadership and the Work Outcomes of Chinese Migrant Workers: The Mediating Effects of Identification with Leader." Leadership 8 (4):377-95. doi: 10.1177/1742715012444055.

Morgan, Robert M., and Shelby D. Hunt. 1994. "The CommitmentTrust Theory of Relationship Marketing." Journal of Marketing 58 (3):20-38. doi: 10.1177/002224299405800302.

Mulki, Jay Prakash, Barbara Caemmerer, and Githa S. Heggde. 2015. "Leadership Style, Salesperson's Work Effort and Job Performance: The Influence of Power Distance." Journal of Personal Selling \& Sales Management 35 (1):3-22. doi: 10.1080/08853134.2014.958157.

Nowlin, Edward L., Doug Walker, and Nwamaka Anaza. 2019. "The Impact of Manager Likeability on Sales Performance." Journal of Marketing Theory and Practice 27 (2):159-73. doi: 10.1080/ 10696679.2019 .1577684$.

Palmatier, Robert W., Cheryl Burke Jarvis, Jennifer R. Bechkoff, and Frank R. Kardes. 2009. "The Role of Customer Gratitude in Relationship Marketing.” Journal of Marketing 73 (5):1-18. doi: 10. 1509/jmkg.73.5.1.

Peesker, Karen M., Lynette J. Ryals, Gregory A. Rich, and Susan E. Boehnke. 2019. "A Qualitative Study of Leader Behaviors Perceived to Enable Salesperson Performance." Journal of Personal Selling \& Sales Management 39 (4):319-33. doi: 10.1080/08853134.2019. 1596816.

Pelser, Jan, Ko de Ruyter, Martin Wetzels, Dhruv Grewal, David Cox, and Jacqueline van Beuningen. 2015. "B2B Channel Partner Programs: Disentangling Indebtedness from Gratitude." Journal of Retailing 91 (4):660-78. doi: 10.1016/j.jretai.2015.05.006.

Plank, Richard E., David A. Reid, Steven E. Koppitsch, and Jeffrey Meyer. 2018. "The Sales Manager as a Unit of Analysis: A Review and Directions for Future Research." Journal of Personal Selling \& Sales Management 38 (1):79-91. doi: 10.1080/08853134.2017. 1423230

Pratt, Michael G. 1998. "To Be or Not to Be: Central Questions in Organizational Identification." In Identity in Organizations: Building Theory through Conversations, edited by D. A. Whetten and P. C. Godfrey, 171-207. Thousand Oaks, CA: Sage.

Raven, Bertram H. 2008. "The Bases of Power and the Power/ Interaction Model of Interpersonal Influence." Analyses of Social Issues and Public Policy 8 (1):1-22. doi: 10.1111/j.1530-2415.2008. 00159.x.

Rich, Gregory A. 1997. "The Sales Manager as a Role Model: Effects on Trust, Job Satisfaction, and Performance of Salespeople." Journal of the Academy of Marketing Science 25 (4):319-28. doi: 10.1177/ 0092070397254004

Schetzsle, Stacey, and Duleep Delpechitre. 2013. "The Impact of Sales Manager Characteristics on Salesperson's Trust and Commitment to the Relationship." Marketing Management Journal 23 (1):102-19.

Schwepker, Charles H. 2019. "Using Ethical Leadership to Improve Business-to-Business Salesperson Performance: The Mediating Roles of Trust in Manager and Ethical Ambiguity." Journal of Business-toBusiness Marketing 26 (2):141-58. doi: 10.1080/1051712X.2019. 1603358.

Shamir, Boas, Robert J. House, and Michael B. Arthur. 1993. "The Motivational Effects of Charismatic Leadership: A Self-Concept Based Theory." Organization Science 4 (4):577-94. doi: 10.1287/orsc. 4.4.577.

Shanahan, Kevin J., and Christopher D. Hopkins. 2019. "Level of Agreement between Sales Managers and Salespeople on the Need for Internal Virtue Ethics and a Direct Path from Satisfaction with Manager to Turnover Intent." Journal of Business Ethics 159 (3): 837-48. doi: 10.1007/s10551-018-3813-6. 
Shi, Huanhuan, Shrihari Sridhar, Rajdeep Grewal, and Gary Lilien. 2017. "Sales Representative Departures and Customer Reassignment Strategies in Business-to-Business Markets." Journal of Marketing 81 (2):25-44. doi: 10.1509/jm.15.0358.

Simons, Tony. 2002. "Behavioral Integrity: The Perceived Alignment between Managers' Words and Deeds as a Research Focus." Organization Science 13 (1):18-35. doi: 10.1287/orsc.13.1.18.543.

Simons, Tony, Leigh Anne Liu, Ray Friedman, and Judi McLean Parks. 2007. "Racial Differences in Sensitivity to Behavioral Integrity: Attitudinal Consequences, in-Group Effects, and 'Trickle down' among Black and Non-Black Employees." The Journal of Applied Psychology 92 (3):650-65. doi: 10.1037/0021-9010.92.3.650.

Skiba, Jenifer, Amit Saini, and Scott B. Friend. 2019. "Sales Manager Cost Control Engagement: Antecedents and Performance Implications." Journal of Personal Selling \& Sales Management 39 (2):123-37. doi: 10.1080/08853134.2018.1548284.

Sluss, David M., and Blake E. Ashforth. 2008. "How Relational and Organizational Identification Converge: Processes and Conditions." Organization Science 19 (6):807-23. doi: 10.1287/orsc.1070.0349.

Sun, Jiaqing, Robert C. Liden, and Linyi Ouyang. 2019. "Are Servant Leaders Appreciated? an Investigation of How Relational Attributions Influence Employee Feelings of Gratitude and Prosocial Behaviors." Journal of Organizational Behavior 40 (5):528-40. doi: 10.1002/job.2354.

Sunder, Sarang, V. Kumar, Ashley Goreczny, and Todd Maurer. 2017. "Why Do Salespeople Quit? An Empirical Examination of Own and Peer Effects on Salesperson Turnover Behavior." Journal of Marketing Research 54 (3):381-97. doi: 10.1509/jmr.15.0485.

Tajfel, Henri, and John Turner. 1986. "The Social Identity of Intergroup Behavior." In Psychology and Intergroup Relations, edited by Stephen Worchel and William G. Austin, 7-24. Chicago, IL: Nelson-Hall.

Thompson, A. D., Myranda Grahek, Ryan E. Phillips, and Cara L. Fay. 2008. "The Search for Worthy Leadership." Consulting Psychology Journal: Practice and Research 60 (4):366-82. doi: 10.1037/10659293.60.4.366.

Uhl-Bien, Mary, Ronald E. Riggio, Kevin B. Lowe, and Melissa K. Carsten. 2014. "Followership Theory: A Review and Research Agenda." The Leadership Quarterly 25 (1):83-104. doi: 10.1016/j.leaqua.2013.11.007.

van Knippenberg, Daan, and Sim B. Sitkin. 2013. "A Critical Assessment of Charismatic-Transformational Leadership Research: Back to the Drawing Board?" Academy of Management Annals 7 (1): 1-60. doi: 10.1080/19416520.2013.759433.

Waldman, David A., Min Z. Carter, and Peter W. Hom. 2015. "A Multilevel Investigation of Leadership and Turnover Behavior." Journal of Management 41 (6):1724-44. doi: 10.1177/ 0149206312460679.

Wang, Rui, Aditya Gupta, and Rajdeep Grewal. 2017. "Mobility of Top Marketing and Sales Executives in Business-to-Business Markets: A Social Network Perspective." Journal of Marketing Research 54 (4) 650-70. doi: 10.1509/jmr.14.0124.

Whitener, Ellen M., Susan E. Brodt, M. A. Korsgaard, and Jon M. Werner. 1998. "Managers as Initiators of Trust: An Exchange Relationship Framework for Understanding Managerial Trustworthy Behavior." Academy of Management Review 23 (3):513-30. doi: 10 5465/amr.1998.926624.

Wieseke, Jan, Michael Ahearne, Son K. Lam, and Rolf van Dick. 2009. "The Role of Leaders in Internal Marketing." Journal of Marketing 73 (2):123-45. doi: 10.1509/jmkg.73.2.123. 


\section{Appendix. Construct scales and sources}

\section{Construct/Source \\ Manager Competence}

Manager Charisma

(Bass and Avolio 1997)

Manager Behavioral Integrity

Identification with Manager

(Mael and Ashforth 1992)

Trust in Manager

(Mackenzie, Podsakoff, and Rich 2001)

Turnover Intentions

(Bluedorn 1982)

Gratitude toward Manager

(Palmatier et al. 2009)

Sales Performance
(Mayer and Davis 1999)

(Simons et al. 2007)

(Miao and Evans 2007)

Indicators

My manager:

1. Is very capable of performing his/her job

2. Contributes a lot to my company's performance

3 . Is knowledgeable about the work that needs to be donels

4. Is well qualified

My manager:

1. Shows determination when accomplishing goals.

2. Communicates high performance expectations.

3. Transmits a sense of mission

4. Provides a vision of what lies ahead.

1. There is a match between my manager's words and actions.

2. My manager practices what he/she preaches.

3. My manager does what he/she says he/she will do.

4. My manager conducts himself/herself by the same values he/she talks about.

1. When someone criticizes my manager, it feels like a personal insult.

2. I am very interested in what others think about my manager*

3. My managers' successes are my successes

4. When someone praises my manager, it feels like a personal compliment.

5. I do identify with my manager.

1. I am confident my manager will treat me fairly

2. I trust my manager

3. My manager would never try to gain an advantage by deceiving his/her subordinates

1. It is likely that I will actively look for a new job this year

2. I often think about quitting my job

3. I will probably look for a new job within a year

1. I am grateful to my manager for his/her contribution to my performance

2. I am thankful to my manager for his/her support in my development

3. I am appreciative of my manager's role in helping me professionally

Evaluate how well you believe you performed in the following areas relative to other salespeople in your organization at the time of your last performance review:

1. Generating a high level of sales (in Dollars)

2. Exceeding sales targets

3. Identifying and cultivating major accounts in your territory

4. Contributing to your company's market share*

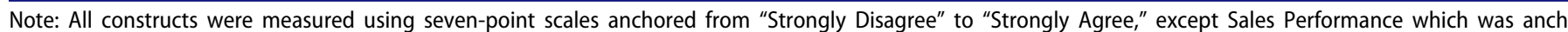
ored from "Much Worse" to "Much Better"); * indicates item was dropped during measure purification process 